\title{
Clinical and morphological justification of the treatment of purulonecrotic lesion in deep structures of limb distal segment in pig: case report
}

\author{
[Justificativa clínica e morfológica do tratamento de lesão purulonecrótica em estruturas \\ profundas do segmento distal de membros em porco: relato de caso ]
}

B. Kyrychko, T. Zvenihorodska*, S. Kravchenko, O. Kyrychko, V. Semirenko

Poltava State Agrarian Academy - Poltava, Ukraine

\begin{abstract}
Surgical pathology of the musculoskeletal system, and in particular the diseases of the limb distal segment in pigs are quite common. Their significant spread leads to economic losses due to culling, compulsory slaughter, short-received pig production and pig crop. The purpose of this work was to reveal clinical and morphological features of limb distal segment diseases in pigs and to study the possibility of preserving their health and productivity. The conservative treatment of purulonecrotic lesions in the deep structures of the limb distal segment in pigs is not promising. It is shown that the best way to treat a given pathology is amputation of a sick limb. The technique of carrying out exarticulation of talus shin consists in separation of soft tissues, capsule and ligaments, ligation of vessels, formation of stump. The postoperative recovery period of the animal body is 25 days.
\end{abstract}

Keywords: pig, limb distal segment, purulonecrotic lesion, amputation

\section{RESUMO}

A patologia cirúrgica do sistema musculoesquelético e, em particular, as doenças do segmento distal dos membros em suínos são bastante comuns. A sua propagação significativa leva a perdas econômicas devido ao abate seletivo, abate obrigatório, produção de suínos pouco recebida e colheita de suínos. O objetivo deste trabalho foi revelar características clínicas e morfológicas das doenças do segmento distal de membros em suínos e estudar a possibilidade de preservar sua saúde e produtividade. $O$ tratamento conservador das lesões purulonecróticas nas estruturas profundas do segmento distal do membro em porcos não é promissor. Fica estabelecido que a melhor forma de tratar uma determinada patologia é a amputação de um membro doente. A técnica de realizar a exarticulação da canela do talos consiste na separação dos tecidos moles, cápsula e ligamentos, ligadura dos vasos, formação do coto. O período de recuperação pós-operatória do corpo do animal é de 25 dias.

Palavras-chave: porco, segmento distal de membro, lesão purulonecrótica, amputação

\section{INTRODUCTION}

The introduction of intensive technologies in modern pig breeding allows, at minimal investments, to increase the productivity of pigs and to improve the working conditions of service personnel. Optimization of livestock, material and labor systems increases the efficiency of obtaining healthy pigs. Housing a large number of pigs in group pens and lack of exercise combined with malnutrition increase the risk of the musculoskeletal diseases (Burdenyuk \& Vlasenko, 1985; Borisevich, 1991, 2007; Podobed et al., 2011, Van de Weerd; Day, 2009). Diseases of the limb distal segment lead to a worldwide decline in producing ability of pigs in different age groups, posing a serious threat to the well-being of replacement and breeding livestock (KilBride et al., 2009).

In many countries around the world hog nail diseases rank second in breeding pigs disposal,

Recebido em 17 de junho de 2020

Aceito em 10 de agosto de 2020

*Autor para correspondência (corresponding author)

E-mail: tzvenig@gmail.com 
accounting for $10-20 \%$ of slaughtered livestock (Dagorn and Aumaitre, 1979; Webb et al., 1983; Lopes-Serrano et al., 2000; Tarres et al., 2006). Sow lameness spread is $13.1 \%$ in Norway (Gjein \& Larssen, 1995), 8.8\% in Finland (Heinonen et al., 2006), $15 \%$ in Denmark (Bonde et al., 2004) and in Belgium (Pluym et al., 2011). Piglet lameness cases are $4 \%$ in Scotland (Smith \& Morgan, 1997) and 1-2\% in Switzerland (Van den Berg et al., 2007). Studying pigs in England KilBride et al. (2009) noted the lameness spread up to $16.9 \%$ among sows and up to $14.6 \%$ among replacement pigs.

Analysis of the literature makes it possible to conclude that the surgical pathology of the musculoskeletal system, and in particular the diseases of the limb distal segment in pigs are quite common. Their significant spread leads to economic losses due to culling, compulsory slaughter, short-received pig production and pig crop.

\section{MATERIALS AND METHODS}

The investigation was conducted in pig farms of VAT "Smak Myrhorodshchyny" (open jointstock company "Taste of Mirgorod area") in Myrhorod district, Poltava region, Ukraine. The pigs were kept in typical quarters with concrete floors, according to groups: weaning piglets, growing-fattening pigs, replacement pigs and sows. Our research subject was purulonecrotic lesions in the deep structures of the limb distal segment in Large White and Landrace pigs. This pathology is most often recorded in sows after the fourth farrowing, as well as in weaning piglets, mainly on the hind limbs.

The purpose of this work was to reveal clinical and morphological features of limb distal segment diseases in pigs and to study the possibility of preserving their health and productivity. Two pigs were taken for the study. To achieve this goal, we applied a battery of general and specific clinical research methods used in Ukraine. Drugs used for anesthesia: sevoflurane, zoletil, lidocaine, propofol - even, the patients were stable for the entire operation for 2.5 hours, did not show any signs of pain, heart rate $90-95$, ventilation mode Simv, CO2 35-45, Fio2 65-70, flow 10ml/kg/min.

Animal housing conditions and experimental research methods complied with the provisions of the European Convention for the Protection of Vertebrate Animals Used for Experimental and Other Scientific Purposes (EES, 1986). The reserch protocol of the courent study was appruved by the Ethic Committee of Poltava State Agrarian Academi (Aprobal number 2020/04.

\section{RESULTS AND DISCUSSION}

Diseases of the deep structures of the hoof (Figure 1) belong to the group of surgical diseases affecting joint, tendon and bone apparatus of the limb distal segment. First of all, this group includes arthritis and osteomyelitis, that, according to our data (Kirichko et al., 2015; Kirichko \& Semirenko, 2016), depending on the age group, account for 0.1 to $4 \%$ of all limb diseases in pigs.

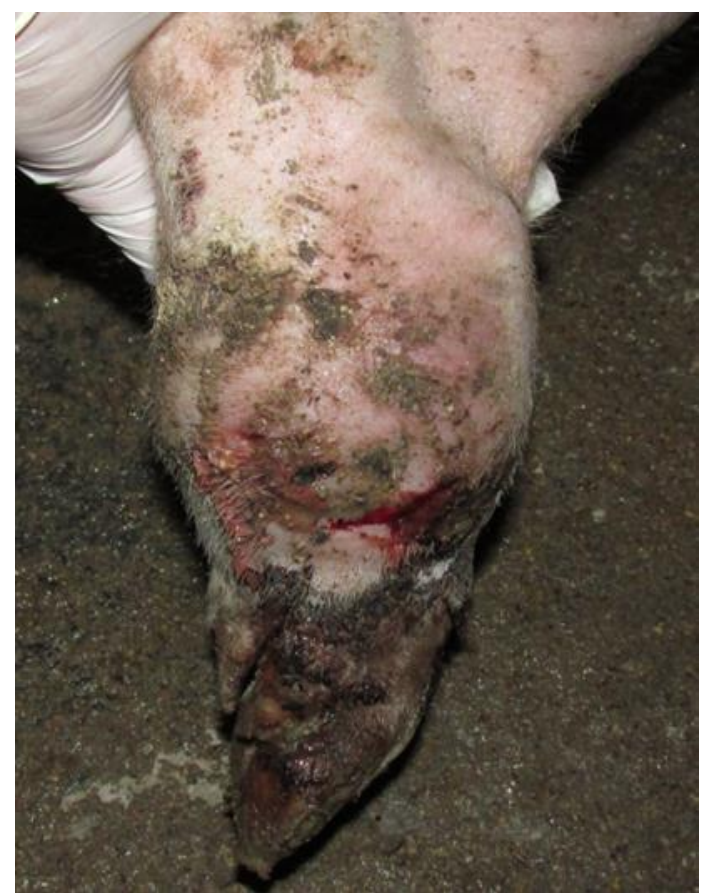

Figure 1. Limb distal segment of a pig with purulonecrotic lesion of the deep tissue structures.

Arthritis is an inflammation of the joint capsule and adjacent collateral ligaments due to joint tissue trauma or chronic specific infection (chlamydiosis, mycoplasmosis). The tissue of the affected joint is tense on palpation, hot to the touch, there is severe pain reaction. The sick pig lies down, seldom gets up; lameness of III-IV degrees is observed. Excessive fluid in the joint cavity stretches the capsule, forming a fistula for fibrinopurulent exudate to go out. Arthritis was 
recorded on one or two limbs, in rare cases at all of them.

Osteomyelitis is an inflammation of the bone marrow and bone tissue in the thickness of the cortical layer, followed by its destruction. It occurs due to the significant traumatization of tissues with the microbial contamination of the bone base. Sick pigs are restless, they lose appetite, lameness up to IV-V stages is intensively developed. On palpation, severe pain reaction was observed, the tissues were swollen, and the local temperature was high. X-ray images show characteristic features (Figure 2).

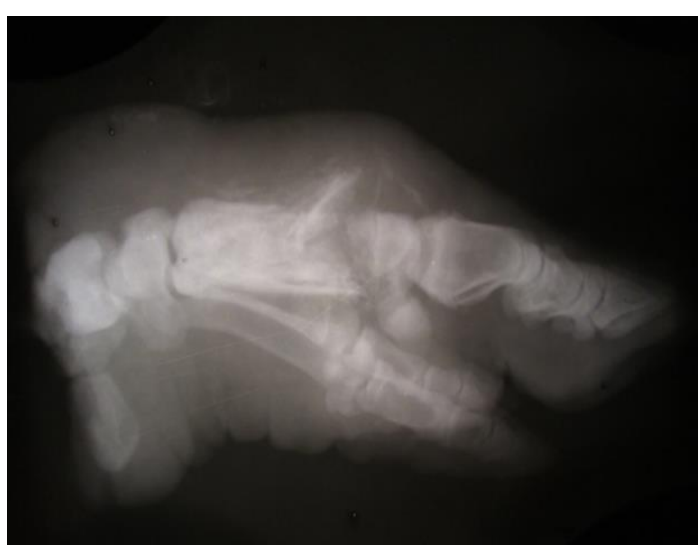

Figure 2. Post-traumatic osteomyelitis of the metacarpale.

The X-ray shows the area of osteolysis of the epiphyseal-diaphyseal part of the metacarpal bone. Bone destruction also extends into the joint cavity, which is characteristic of osteomyelitis and infectious arthritis. Pathological material the distal part of the affected limb - was taken from the sick pigs subjected to sanitary slaughter. The material was frozen and longitudinal sections of tissues were performed within the frames of the affected areas (Figure 3-5).

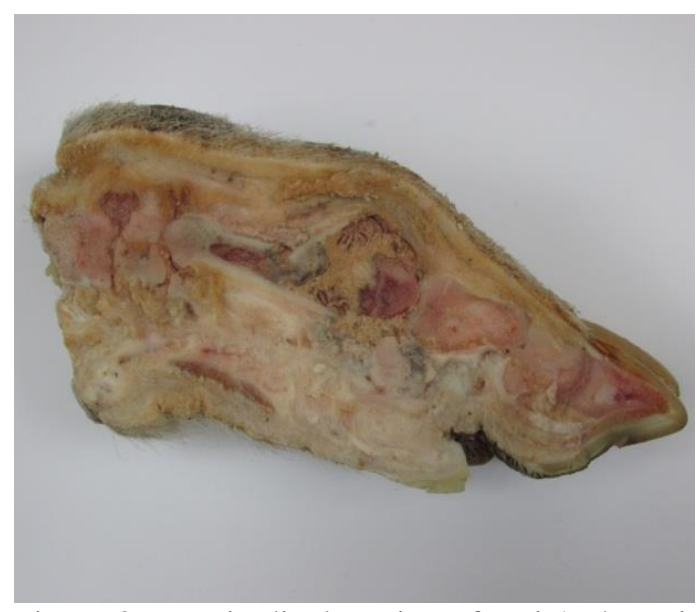

Figure 3. Longitudinal section of a pig's thoracic limb tissues at the level of the third metacarpal bone.

Figure 3 shows the distal epiphyseal fracture of the third metacarpal bone, the destruction of the dorsal part of the diaphysis, the accumulation and spread of purulent exudate into the surrounding tissues and the joint cleft. We see a similar pattern with hind limb lesions. Thus, Figure 4 clearly shows the destruction of the epiphyseal part of the metatarsal bone, the accumulation of exudate in the bone cavity and its spread dorsally and into the joint cleft. There is a tendency of fistula formation.

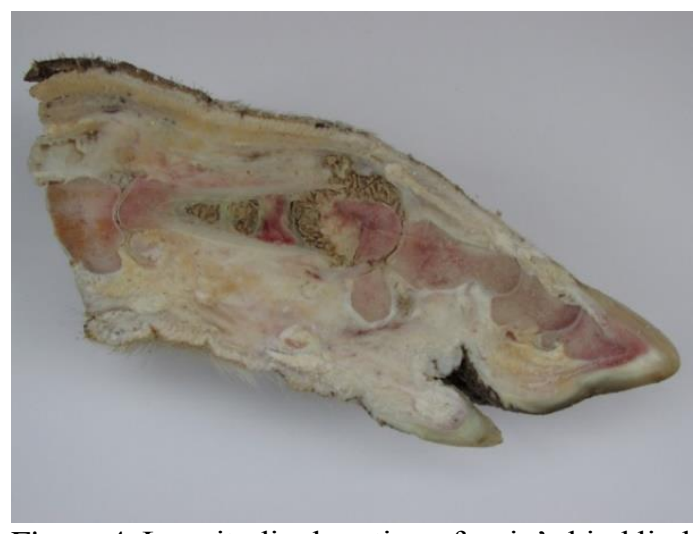

Figure 4. Longitudinal section of a pig's hind limb tissue at the level of the fourth metatarsal bone. 


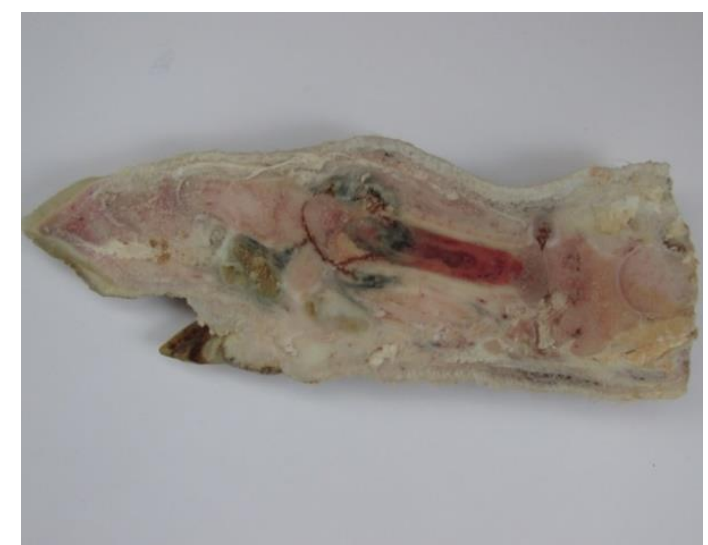

Figure 5. Longitudinal section of a pig's hind limb tissue at the level of the fourth metatarsal bone.

Inflammatory destructive phenomena in the area of the epiphyseal-diaphyseal fusion we observed in other clinical cases as well (Figure 5). The inflammatory process extends to the cortical layer of the diaphysis of the metacarpal bone, bone marrow, and the metacarpophalangeal joint capsule. The conservative treatment of purulonecrotic lesions in the deep structures of the limb distal segment in pigs is unpromising. The only effective way to treat such a pathology is the removal of the peripheral part of the organ, i.e. amputation. The best long-term results were obtained after hind limb surgery in young animals. For this purpose, an exarticulation tactic of the ankle mortise joint was developed.

The operation can be performed in a pig farm, preparing the animal with a 12 hour fast. After the introduction of the animal into general anesthesia, fixation in the dorsal position, preparation of the operative field and local anesthesia, a circular incision of the skin was performed, $3 \mathrm{~cm}$ more proximal of the ankle joint. Then the skin was dissected to the tibia. From the caudal side of the limb above the calcaneus, the artery and the saphenous vein were sutured up to the heel muscle. The tibial artery from the cranial side of the limb was stitched with a piercing ligature up to the eponymous muscle. The dorsal ankle artery was stitched with ligature up to the transverse ligament of tibia.

On the cranial side, exarticulation was performed below the transverse ligament of tibia. The heel tendon of the eponymous muscle was dissected close to the head of the calcaneus, taking as much as possible of the connective tissue. All ligaments were separated at the level of the joint middle, exposing the head of the distal part of the tibia and fibula. The cartilage was separated with a raspatory. With single sutures the skin was stitched to the tendons and muscles, then the shape of the suture was corrected. The edges of the skin wound were connected with interrupted stitches, drainage was put in to remove excess exudate. In the postoperative period antibiotics and anti-inflammatory drugs, stimulants and vitamins were used. Throughout the keeping period, the operated animals moved freely on three limbs (Figures. 6,7), and their weight gain did not differ from that of healthy animals.

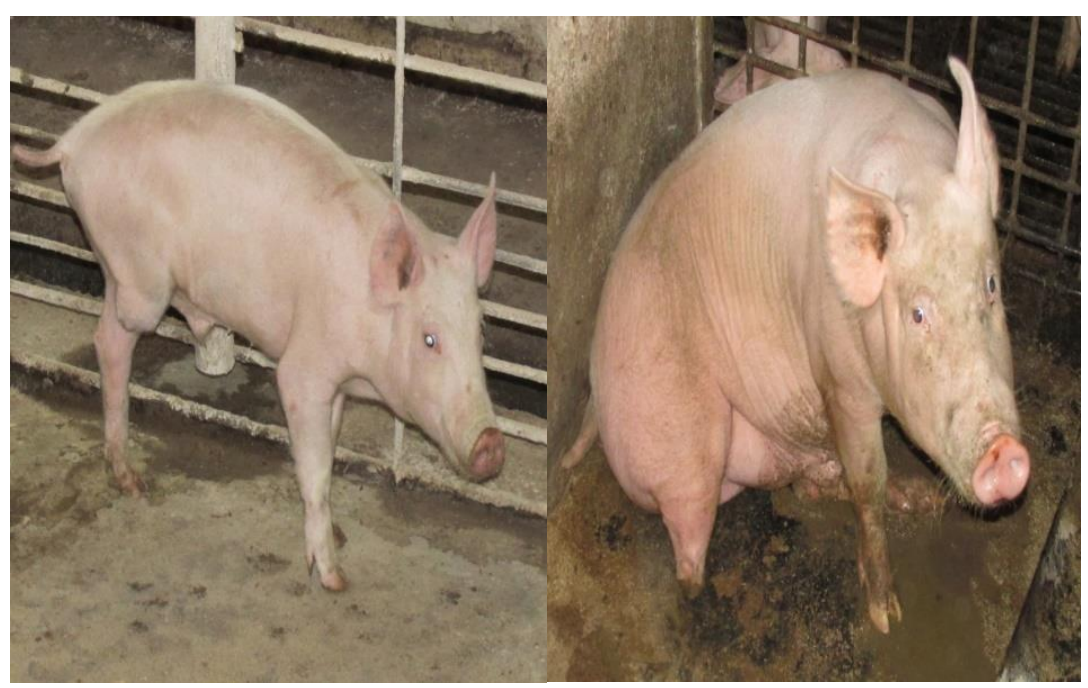

Figure 6. A 2.5-month-old animal

Figure 7. A 6.5-month-old animal 
As complex forms of surgical diseases of the deep structures of the limb distal segment (most often osteomyelitis, purulent arthritis and their complications) with impaired function of the musculoskeletal system in pigs are disclosed, there arises a task for their treatment. Most experts (Timofeev et al., 2007; Vlasenko \& Tihonyuk, 1998, Veremej et al., 2010) believe that an effective treatment method can only be the operative one. Surgical treatment should be aimed at eliminating purulonecrotic process by removing the affected tissues within the frames of the healthy ones. In chronic forms of osteomyelitis, treatment is performed surgically (sequestrotomy), using antibiotics and sulfonamides. These authors recommend subperiosteal lesion removal since subsequently it results in periosteal osteogenesis.

Vlasenko \& Tihonyuk (1998) for the pathology of the deep structures of the limb distal segment in pigs, recommend the limb amputation by osteotomy. Burdenyuk \& Vlasenko (1985) recommend using Roeder's exarticulation technique, saving the main part of the coronet and all the bulb of the heel in pigs. It should also be remembered that after exarticulation of the II and III phalanges of the fingers the postoperative treatment period is longer than after the high amputation (Molokanov et al., 2003). We have tested the technique of high limb amputation in pigs by exarticulation of the ankle mortise joint (Semirenko, 2016). It was this operation that gave the best result in terms of keeping up health and productivity of sick pigs.

\section{CONCLUSION}

Thus, limb exarticulation is the only effective treatment for surgical diseases of the deep structures of the limb distal segment in pigs, which allows to preserve the life and productivity of the animal. Ankle mortise joint exarticulation technique involves separation of soft tissues, capsule and ligaments, ligation of vessels, formation of the stump. The postoperative recovery of the animal amounts to 25 days.

\section{REFERENCES}

BONDE, M.; ROUSING, T.; BADSBERG, J.H.; SØRENSEN, J.T. Associations between lyingdown behaviour problems and body condition, limb disorders and skin lesions of lactating sows housed in farrowing crates in commercial sow herds. Livest. Prod. Sci., v.87, p.179-187, 2004.

BORISEVICH, V.B. Veterinary orthopedics: hoof disease. Kiyiv, Ukraine: Dia, 2007.

BORISEVICH, V.B. Technological diseases of farm animals. Belaya cerkov: tezisy vsesoyuznoj nauchnoj konferencii Problemy hirurgicheskoj patologii s.-h. Zhivotnyh, p.58-59, 1991.

BURDENYUK A.F.; VLASENKO V.M. Surgery in industrial pig breeding. Visha shkola, Rusian: Kiev, 1985.

DAGORN, J.; AUMAITRE, A. Sow culling: reasons for and effect on productivity. Livest. Prod. Sci., v.6, p.167-177, 1979.

EEC. Council Directive 86/609/EEC of 24 November 1986 on the approximation of laws, regulations and administrative provisions of the Member States regarding the protection of animals used for experimental and other scientific purposes. Official Journal of the European Communities, 1358, p.1-29, 1986.

GJEIN, H.; LARSSEN, R.B. The effect of claw lesions and claw infections on lameness in loose housing of pregnant sows. Acta Vet. Scand., v.36, p.451-459, 1995.

HEINONEN, M., ORAVAINEN, J., ORRO, T. et al. Lameness and fertility of sows and gilts in randomly selected loose-housed herds in Finland. Vet. Rec., v.159, p.383-387, 2006.

KILBRIDE, A. L.; GILLMAN, C.; OSSENT, P.; GREEN, L.E. Impact of flooring on the health and welfare of pigs, In Pract., v.8, p.390-395, 2009.

KILBRIDE, A.L.; GILLMAN, C.E.; GREEN, L.E. A cross-sectional study of the prevalence of lameness in finishing pigs, gilts and pregnant sows and associations with limb lesions and floor types on commercial farms in England. Anim.Welf., v.18, p.215-224, 2009.

KIRICHKO, B.P.; SEMIRENKO, V.V. Clinical forms of distal limb pathology in pigs. ScienceRise, v.1, p.20-26, 2016. 
KIRICHKO, B.P.; ZVENIGORODSKA, T.V.; SEMIRENKO, V.V. Clinical and radiological characteristics of inflammatory-purulent processes of distal limb in pigs. Visnik Poltavskoyi Derzhavnoyi Agrarn. Akad., v.4, p.55-57, 2015.

LOPEZ-SERRANO, M.; REINSCH, N.; LOOFT, H.; KALM, E. Genetic correlations of growth, backfat thickness and exterior with stayability in large white and landrace sows, Livest. Prod. Sci., v.64, p.121-131, 2000.

MOLOKANOV, V.A.; SEMYONOV, B.S.; KAMSAEV, K.M. Diseases of hoofs of farm animals. Chelyabinsk: Konus, 2003.

PLUYM, L.; VAN NUFFEL, A.; DEWULF, J. et $a l$. Prevalence and risk factors of claw lesions and lameness in pregnant sows in two types of group housing. Vet. Med., v.56, p.101-109, 2011.

PODOBED L.I., RUDENKO E.V., SOLDATOV A.A. et al. Prevention of production disturbances in intensive pig production. Odessa: Pechatnyj Dom, 2011.

SEMIRENKO, V.V. Efficiency of exarticulation in purulent-inflammatory lesions of distal extremities in pigs. Sovremennye problemy veterinarnoj hirurgii. Vitebsk: VGAVM, 2016.

SMITH, B.; MORGAN, M. The role played by the floor surface in the development of claw lesions in the pig. Project Report, SAC Veterinary Sciences Division. Aberdeen: Scottish Agricultural College, 1997.
TARRES, J.; TIBAU, J.; PIEDRAFITA, J.; FABREGA, E.; REIXACH, J. Factors affecting longevity in maternal Duroc swine lines. Livest. Sci., v.100, p.121-131, 2006.

TIMOFEEV, S.V.; FILIPPOV, YU.I.; KONCEVAYA, S.Y.U. General surgery of animals. Moskva: Zoomedlit,. 2007.

VAN DE WEERD, H.A.; DAY, J.E.L. A review of environmental enrichment for pigs housed in intensive housing systems. Appl. Anim. Behav. Sci., 116, p.1-20, 2009.

VAN DEN BERG, A.; DANUSER, J.; FREY, J.; REGULA, G. Evaluation of the acute phase protein haptoglobin as an indicator of herd health in slaugahter dies. Anim. Welf., v.16, p.157-159 2007.

VEREMEJ E.I., STEKOLYSHKOV A.A., SEMYONOV B.S. et al. Clinical surgery in veterinary medicine. Minsk: IVC Minfina, 2010.

VLASENKO V.N.; TIHONYUK L.A. Surgery in pig and sheep breeding. Moskva: Urozhaj, 1998.

WEBB, A.J.; RUSSELL, W.S.; SALES, D.I. Genetics of leg weakness in performance-tested boars. Anim. Prod., v.36, p.117-130, 1983. 